\title{
CÁC YẾU TỐ ẢNH HƯởNG ĐẾN KẾT QUẢ HOẠT ĐộNG TÀI CHÍNH: PHÂN TÍCH TRƯỜNG HỢPCỦA BỂNH VIÊ̂N UNG BƯỚU THÀNH PHỐ HỒ CHÍ MINH GIAI ĐOÂN 2014-2018
}

\section{TÓM TẮT}

Muc tiêu: Phân tích các yếu tố ảnh hưởng đến kết quả hoạt động tài chính của Bệnh viện Ung bướu Thành phố Hồ Chí Minh trong giai đoan 2014-2018. Phương pháp nghiên cứu: Nghiên cứu tính, phỏng vấn sâu 07 lãnh đạo quản lý của bệnh viện và thảo luận nhóm 2 nhóm cán bộ y tế. Kết quả và kết luần: Các yếu tố bên gồm cấu trúc đặc thù của bệnh viện; sự vận hành linh hoạt giúp tăng cường số lượng và chất lượng hoạt động chuyên môn; chiến lược phát triển; đặc điểm về nhân lực; hệ thống công nghệ thông tin. Các yếu tố bên ngoài gồm ảnh hưởng của chính sách (chỉnh sách tự chủ, bảo hiểm y tế, viện phí) và ảnh hưởng của "thị trường" (sự gia tăng của số người mới mắc ung thư và tỷ lệ người bệnh giai đoạn muộn; ảnh hưởng của các bệnh viện đa khoa có khoa điều trị ung thư trên địa bàn).

Từ khóa: tài chính bệnh viện, yếu tố bên trong, yếu tố bên ngoài, quản lý tài chính

\section{SUMMARY}

\section{THEFINANCIAL PERFORMANCE OF HO CHI MINH CITY ONCOLOGY HOSPITAL FROM \\ 2014 TO 2018}

Objective: Analyzing the factors affecting the financial performance of Ho Chi Minh City Oncology Hospital in the period 2014-2018. Method: Employing qualitative design. In-depth interviews were conducted with 07 hospital management leaders. Focus group discussions were conducted with 2 groups of medical staff. Results and Conclusions: The organizationalfactors include the specific structure of the hospital; flexible operations increase the quantity and quality of expertise; development strategy; human characteristics; information technology system. Environmental factors include the impact of the policy (hospitalautonomypolicy, health insurance, hospital fees) and the impact of the "market" (the increase in incidence cases and the proportion of patients with latestage; influence of localgeneral hospitals with cancer treatment departments.

Keywords: financial performance, structural factor, operational factor, strategic management, staffing factors, market factor.

${ }^{1}$ Trường Đai hoc Y tế Công công

²Bênh viện Ung bướu Thành phố Hồ Chí Minh

${ }^{3}$ Bềnh viện Phổi Trung Ương

Chịu trách nhiệm chính: Nguyễn Quỳnh Anh

Email: nqa@huph.edu.vn

Ngày nhận bài: 22.3.2021

Ngày phản biên khoa hoc: 10.5.2021

Ngày duyệt bài: 24.5.2021
Nguyễn Quỳnh Anh ${ }^{1}$, Nguyễn Thu Hà ${ }^{1}$, Nguyễn Thị Ngọc Uyên ${ }^{2}$, Vũ Xuân Phú ${ }^{3}$

\section{I. ĐẶT VẤN ĐỀ}

Bệnh viện Ung Bướu Thành phố Hồ Chí Minh là đớn vị sự nghiệp công tự đảm bảo một phần chi phí theo Nghi đinh 43/2006/NĐ-CP từ năm 2006 đến năm 2016. Đến 2017, Bệnh viện là đơn vị sự nghiệp tự đảm bảo toàn bộ chi phí hoạt động thường xuyên theo Nghị định 16/2015/NĐ-CP. Cuối năm 2020, cùng với cơ sở 1 , cơ sở 2 tại Quận 9 với quy mô 1.000 giường bắt đầu hoạt động. Hiện nay, nguồn thu của bệnh viện gồm thu từ ngân sách nhà nước (NSNN) và thu sự nghiệp. Thu sự nghiệp bao gồm thu viện phí (thu không bảo hiểm y tế (BHYT), thu đồng chi trả, thu BHYT) và thu dịch vụ (khám chữa bệnh (KCB) theo yêu câu, phòng khám ngoài giờ, nhà thuốc, và xã hội hóa). Tổng thu của bệnh viện tăng dần, từ 921 tỷ đồng vào 2014 lên 1.693 tỷ đồng vào 2018 (tăng 1,86 lần). Tổng chi năm 2018 tăng 1,86 lần so với năm 2014, chủ yếu là chi cho chuyên môn nghiệp vụ (chiếm khoảng 80\%).

Trên thế giới, Nurettin Oner và cộng sự (2016) tiến hành tổng quan hệ thống trên 81 nghiên cứu thực hiện từ năm 1996 đến năm 2016 về các yếu tố ảnh hưởng đến kết quả hoạt động tài chính của các bệnh viện [1] cho thẩy ảnh hưởng của nhóm các yếu tố thuộc về bên trong và bên ngoài bênh viên: yếu tố cấu trúc (structural factor), yễu tố vận hành (operational factor), yếu tố quản lý chiến lược (strategic), yếu tố nhân lực (staffing factors), yếu tố thị trường (market factor). Yếu tố cấu trúc đề cập đến đặc điểm của bệnh viện, quy mô và cách thức tổ chức quản lý. Yếu tố vận hành đề cập đến hoạt động chuyên môn hàng ngày. Yếu tố quản lý chiến lược đề cập đến chiến lược phát triển. Yếu tố nhân lực đề cập đến các biện pháp liên quan đến việc sử dụng nguồn lao động phù hợp với chuyên môn. Yếu tố về thị trường liên để cập đến môi trường kinh tế - xã hội, gánh năng bênh tật. Bên cạnh đó, tại Việt Nam, yếu tố chính sách được nhiều tác giả đề cập đến là có ảnh hưởng đên kết quả hoạt động tài chính, đặc biệt là chính sách tự chủ tài chính, các chính sách liên quan đến BHYT, viện phí, liên doanh-liên kết... Bài báo này tập trung phân tích các yếu tố ảnh 
hưởng đến kết quả hoạt động tài chính của Bênh viện Ung bướu Thành phố Hồ Chí Minh trong giai đoan kể từ khi bệnh viện tiến hành tự chủ một phẩn đến khi tự chủ hoàn toàn về tài chính (từ 2014-2018).

\section{II. ĐỐI TƯỢNG VÀ PHƯƠNG PHÁP NGHIÊN CỨU \\ Thiết kế nghiên cứu: nghiên cứu định tính}

Đối tượng nghiên cứu: Lãnh đạo Bệnh viện, quản lý các khoa phòng trong bệnh viện và các CBYT. Tiêu chí lựa chọn đối tượng là người đã làm việc tại bênh viện ít nhất 3 năm và có kinh nghiệm về chủ đề nghiên cứu.

Đia điểm và thời gian nghiên cứu: Thực hiện từ tháng 4/2019 đến tháng 10/2019 tại Bềnh viên Ung bướu Thành phố Hồ Chí Minh

Phương pháp thu thập số liệu: Sử dụng hướng dẫn phỏng vấn sâu (PVS) để PVS 07 đối tượng bao gồm 01 lãnh đạo bệnh viện và 06 quản lý các khoa phòng (Phòng Kế hoach tổng hợp, Phòng Tài chính kế toán, Phòng Tổ chức cán bộ, Phòng Hành chính quản trị, Phòng Vật tư trang thiết bị y tế (TTBYT) và Khoa dược) và sử dụng hướng dẫn thảo luận nhóm (TLN) để thực hiện 2 cuộc TLN (6 đối tượng/nhóm) với các CBYTT.

\section{Chủ đề nghiên cứu:}

- Tìm hiểu các yếu tố ảnh hưởng đến kết quả hoạt động tài chính của bệnh viện Ung bướu Tp Hồ Chí Minh

- Tìm hiểu ảnh hưởng của các yếu tố bên trong: yếu tố cấu trúc; yếu tố vận hành; yếu tố quản lý chiến lược; yếu tố nhân lực.

- Tìm hiểu ảnh hưởng của các yếu tố bên ngoài: yếu tố chính sách liên quan đến quản lý tài chính bệnh viện; yếu tố về thị trường.

Phương pháp phân tích số liệu: Ghi âm các cuộc PVS/TLN được gõ băng và mã hóa, phân tích theo chủ đề phù hợp.

Đạo đức trong nghiên cứu: tuân thủ quy định của Hội đồng đao đức Trường Đại học $Y$ tế Công cộng theo quyết định thông qua số 174/2019/YTCC-HD3 (18/04/2019); được sự đồng ý cho phép sử dụng số liệu của Giám đốc Bệnh viện Ung Bướu Tp Hồ Chí Minh.

\section{KẾT QUẢ NGHIÊN CỨU}

\section{1. Ảnh hưởng của nhóm yếu tố bên trong}

3.1.1. Yếu tố cấu trúc. Cấu trúc của bênh viên là bênh viên công "uy tín" trực thuộc Sở Y tế Tp Hồ Chí Minh Bên; đặc thù là bệnh viện "chuyên khoa tuyến cuối" là các yếu tố ảnh hưởng lớn đến kết quả quản lý tài chính.

Cách thức tổ chức quản lý: PVS/TLN đều nhận định giống nhau là khi bệnh viện tự chủ hoàn toàn chi thường xuyên thì lãnh đạo bệnh viện đã "năng động" hơn trong tổ chức quản lý để cung cấp dịch vụ tốt hơn cho người bệnh, giảm thời gian chờ đợi, đầu tư mua sắm TTBYT hiên đai phưc vụ bênh nhân. Việc quản lý thực hiển BHYT với sự thành lâp của Tổ BHYT thuốc Phòng Kế hoạch Tổng hợp (với sự tham gia của 02 nhân viên kế toán) được đánh giá là có tác động tích cực đến kết quả thu BHYT.

3.1.2. Yếu tố vận hành. Kết quả "hoạt động chuyên môn tốt về cả chất lượng và số lượng" là một trong các yếu tố chính được PVS/TLN đánh giá là làm tăng cường nguồn thu cho bêenh viện. Việc đa dạng hóa các hoat động dịch vụ được đánh giá là có ảnh hưởng lớn đến kết quả tài chính bệnh viện và sự hài lòng của người bênh:

"Đa dang hóa nhiều hoat động khám chữa bệnh (dịch vụ theo yêu cầu, Khám tư vấn tầm soát phát hiện sớm bệnh ung thư, khám từ 5 giờ sáng, khám vào thứ bảy và chủ nhât, tổ chức khám tầm soát ung thư tại chỗ cho các cơ quan có nhu cầu) để phục vụ bệnh nhân cũng như giải quyết tình trạng quá tải, đồng thời làm tăng nguồn thu cho bểnh viện" (PVS Lãnh đạo 4)

\subsubsection{Yếu tố quản lý chiến lược}

Chiến lược mở rộng và phát triển. PVS/TLN cho thây chiến lược phát triển Cơ sở 2 tai Quân 9 sẽ làm tăng đáng kể nguồn thu cho bệnh viện, tuy nhiên cũng đặt ra không ít thách thức về quản lý thu-chi:

"Dự kiến quý 4 năm 2020, bệnh viện sẽ tiếp nhận Cơ sở 2 đăt tại Quận 9 sẽ làm tăng nguồn thu cho bênh viện" (PVS Lãnh đạo 4).

"Khi tiếp nhận Cơ sở 2 thì chi phí phát sinh rất nhiều, Phòng Tài chính Kế toán cần kiểm soát chặt để KQHĐTC không bị ảnh hưởng nhiều" (PVS - Lãnh đạo 1)

PVS/TLN cũng khẳng định xu hướng tăng cường nguồn thu của bệnh viện thông qua việc phát triển Cơ sở 1 thành cơ sở y tế kỹ thuât cao có sự phối hợp liên chuyên khoa đáp ứng nhu cầu "du lịch y tế":

"sẽ xây dựng và phát triển Cơ sở 1 trở thành Cơ sở y tế kỹ thuật cao có sự phối hợp liên chuyên khoa đáp ứng nhu cầu du lịch y tế và giảm bệnh nhân ra nước ngoài điều trị. Sở Du lich Thành phố cho biết khách nước ngoài đến Việt Nam chữa bệnh kết hợp du lịch có xu hướng tăng dần. Năm 2018 có 300.000 người nước ngoài đến khám bệnh và 57.000 người điều trị nội trú, mang lại doanh thu trên 2 tỷ đô..." (PVS - Lãnh đạo 1)

Chiên lược thu hút đâu tư trang thiết bi, cơ sở vật chất . Kết quả PVS/TLN cho rằng đầu 
tư TTBYT mặc dù "tốn kém" nhưng giúp tăng cường khả năng cung cấp dịch vụ từ đó tăng nguồn thu cho bệnh viện do"bệnh nhân không phải chuyển sang cơ sở khác". Chiến lược phát triển mở rộng cung cấp dịch vụ kỹ thuật mới

Kết quả PVS/TLN cho thấy ảnh hưởng lớn của việc phát triển các kỹ thuật mới đến "thương hiệu bệnh viện" và tăng cường nguồn thu cho bệnh viện: "Hàng năm, bệnh viện đều phát triển thêm nhiều kỹ thuật mới nhằm nâng cao tay nghề của đội ngũ y bác sĩ, bệnh nhân tin tưởng đến điều trị mà không cần phải ra nước ngoài để điêu trị. Số lượng bệnh nhân biết để đên bệnh viện điều trị ngày càng tăng và làm tăng thương hiệu bệnh viện, tăng nguồn thu cho bệnh viện" (PVS - Lãnh đạo 2).

Ngoài ra, bệnh viện còn phát triển dịch vụ chăm sóc giảm nhẹ phía Nam Việt Nam, hoạt động động giúp tăng cường nguồn thu cho bệnh viện trong giai đoạn tới

"triển khai thành công mô hình Chăm sóc giảm nhẹ tại nhà cho những bệnh nhân ung thư giai đoạn cuối, không còn khả năng điều trị đặc hiệu trong bán kính $15 \mathrm{~km}$... giúp giảm chi phí đi lại, tiết kiệm được thời gian công sức của người chăm sóc, giảm nguy cơ nhiễm trùng bệnh viện, duy trì cuộc sống mức tốt nhất, đồng thời cũng làm tăng thu cho bệnh viện" (PVS - Lãnh đạo 2)

\subsubsection{Yếu tố nhân lực}

Chất lượng và chất lượng $\mathrm{CBYT}$ được đánh giá là ảnh hưởng nhiều đến nguồn thu:

"Bệnh viện có đội ngũ y bác sĩ giỏi, có tay nghề cao sẽ thu hút bệnh nhân tin tưởng đến bệnh viện điều trị, làm tăng nguồn thu cho bệnh viện"(PVS - Lãnh đạo 7)

"số lượng CBYT đủ thì mới đáp ứng nhu cầu điều trị, giảm thời gian chờ đợi của bệnh nhân, bệnh nhân tin tưởng đến điêu trị tại bệnh viện, từ đó làm tăng nguồn thu" (PVS - Lã̃nh đạo 7)

3.1.5. Yếu tố bên trong khác: PVS/TLN cho thấy ảnh hưởng của công nghệ thông tin "rất quan trọng trong quản lý nguồn thu, nhất là thu BHYT, phải kiểm tra được những lỗi do người sử dụng làm sai, kiểm tra trước khi đẩy dữ liệu lên cổng BHYT nhằm giảm thiểu việc sai sót, tránh để xuất toán" (PVS - Lãnh đạo 4).

\subsection{Yếu tố bên ngoài}

\subsubsection{Yếu tố chính sách}

Ảnh hưởng của chính sách tự chủ tài chính. PVS/TLN nhấn mạnh sự thay đổi về nguồn thu của năm 2017 do ảnh hưởng của chính sách tự chủ tài chính:"Năm 2017 là năm bệnh viện khổng còn nhận tiền từ NSNN thì bệnh viện đã có biện pháp tắng thu, giảm chi để bù đắp cho số thu từ NSNN cắt giảm và thực tế số thu đã tăng nhiều hơn so với các năm được NSNN cấp." (PVS - Lãnh đạo 4).

Ảnh hưởng của chính sách BHYT: Chính sách BHYT ảnh hưởng lớn "vì nguồn thu từ BHYT là nguồn thu chủ yếu chiếm tỉ lệ cao nhất". Tuy nhiên cácvăn bản chính sách về BHYT còn nhiêu bất cập gây ra khó khăn trong thanh quyết toán BHYT:

"quy định định mức trên từng thiết bị của một số kỹ thuật như' siêu âm, $X$-Quang,CT, MRI gây khó khăn cho bệnh viện, bệnh nhân phải chờ lâu hơn" (PVS - Lã̃nh đạo 3).

"BHYT vẫn có thể xuất toán và thu hồi vào những năm sau làm cho bệnh viện gặp khó khăn, bệnh viện lại không thể thu lại của người bệnh" (PVS - Lãnh đạo 4)

"Quy định của thổng tư 30 về điều kiện được hưởng các loại thuốc có giá trị cao làm khó cho CBYT, ví dụ Trastuzumab Quỹ BHYT thanh toán $50 \%$ tại bệnh viện hạng đặc biệt, hạng I và bệnh viện chuyền khoa ung bướu hạng II..." (PVS Lãnh đạo 5).

Chính sách vê giá thu viện phí. Kết quả PVS/TLN cho thấy ảnh hưởng về chính sách viện phí: "giá thu cho bệnh nhân BHYT hay không sử dụng BHYT đều phải thực hiện theo đúng thông tư của BYT, giá thu chưa kết cấu đủ chi phí... Các bệnh viện tư lại không bị khống chế gia thu, họ được tính đầy đủ các chi phí đã bỏ ra để thực hiện dịch vụ kỹ thuật" (PVS - Lãnh đạo 4)

Chính sách khác: Kết quả PVS/TLN cho thấy ảnh hưởng của các chính sách liên quan đến "liên doanh, liên kết TTBYT":

"Hiện nay, bệnh viện muốn đầu tư TTBYT phải được Bộ Y tế phê duyệt định mức, muốn liên doanh liển kết TTBYT thì vướng một số quy định của nghị định 151/2017/ND-CP trong khi các bệnh viện tư nhân không bị ảnh hưởng bởi quy định này" (PVS - Lãnh đạo 4)

3.2.2. Yếu tố thị trường. Kết quả PVS/TLN cho thấy sự phát triển khoa ung bướu của một số bệnh viện trong khu vực làm ảnh hưởng rất lớn đến nguồn thu của bệnh viện, các bệnh viện phải nỗ lực nhiều hơn nữa về các mặt, phải đầu tư cơ sở vật chất, TTBYT, đầu tư nguồn nhân lực, nâng cao trình độ chuyên môn, đổi mới phong cách phục vụ của CBYT để thu hút bệnh nhân đến điều trị.

Sự phát triển vê công nghệ y tế: được đánh giá làảnh hưởng đến quản lý tài chính của bệnh viện theo hướng"Hiện tại y học phát triển rất nhanh...Bệnh viện khồng cập nhật kịp thời các kỹ thuật mới hoặc không đầu tư được các 
TTB hiên đại sẽ bị tụt hâu, làm ảnh hưởng đến nguồn thu của bệnh viện" (PVS - Lãnh đạo 1)

Môi trường kinh tế - xã hội: Nhiều yếu tố về môi trường kinh tế xã hội ảnh hưởng tới kết quả hoat đông tài chính của bênh viên gồm sư phát triển kinh tế xã hội của khu vực Tp Hồ Chí Minh khiến nhiều bệnh nhân có nhu cầu điều trị theo yêu cầu nên tổng thu ngày càng tăng:"Người bênh có khả năng về kinh tế muốn được điều trị trong môi trường tốt hơn như được nằm giường dịch vụ, mổ hoặc xạ trị sớm ngoài giờ làm việc, thứ bảy và chủ nhật, hoạt động dịch vu theo yêu câu đã đáp ứng được nhu cầu của họ, hiện tại bệnh viện cũng chỉ giải quyết số lượng có hạn so với nhu cầu" (PVS lãnh đạo 1)

Gánh nặng bệnh tật: "Tỉ lệ mắc bệnh ung thư ngày càng gia tăng" dẫn đến nguồn thu của bệnh viện năm sau cao hơn năm trước.

\section{BÀN LUÂ̂N}

Kết quả của nghiên cứu này phản ánh sự tương đồng về ảnh hưởng của các nhóm yếu tố tươngtựnhư kết quả tổng quan nghiên cứu trên thế giới về các yếu tố ảnh hưởng đến kết quả tài chính của bệnh viện [1]. Đồng thời tương tự như nghiên cứu trong nước của tác giả Nguyến Thị Bích Hường cho thây các yếu tố ảnh hưởng đến kết quả hoạt động tài chính bao gồm: yếu tố liên quan đến đầu tư nâng cấp TTBYT, cơ sở hạ tầng thông qua khả năng huy động vốn đầu tư; yếu tố về tổ chức, cung cấp các dịch vụ cũng như kết quả hoạt động cung cấp dịch vụ (tăng thực hiện các chỉ tiêu chuyên môn, đa dạng hóa các loại hình cung cấp dịch vụ, phát triển kỹ thuật mới và nâng cao chất lượng dịch vụ nhằm tăng cường sự hài lòng của người bệnh). Tác giả Nguyễn Thị Bích Hường cũng phẩn tích về bối cảnh các chính sách ảnh hưởng đến quản lý tài chính nói chung như chính sách tự chủ tài chính, chính sách về viện phí và BHYT có những tác động về mặt môi trường chính sách đến kết quả hoạt động tài chính [2]. Các yếu tố được chỉ ra trong nghiên cứu này cũng đã được phản ánh trong nghiên cứu của Nguyển Thị Nhạn tại Trung tâm Dịch vụ Y tế Bệnh viện Đa khoa Tỉnh Khánh Hòa giai đoạn 2014 - 2016 cho thấy một số yếu tố ảnh hưởng là chính sách, lương, phúc lợi, nguồn nhân lực và cơ sở hạ tầng [3].

Xem xét mô̂t cách chi tiết số liệu hồi cứu số liêu tài chính thực tiễn của bênh viên cũng ủng hộ cho rất nhiều luận điểm được đưa ra dựa trên kết quả PVS/TLN trong nghiên cứu này. Ví du điển hình là cùng với sự hình thành của Tổ BHYT, số tiền bị BHXH trừ sau giám định giảm dần, năm 2018 số từ chối thanh toán là 5,755 tỉ/ 951,139 tỉ đề nghị thanh toán, trong khi năm 2017 là 8,824 tỉ/849,215 tỉ.

Kết quả hoạt động tài chính của bệnh viên cũng được đánh giá là chịu nhiêu ảnh hưởng của việc mở rộng nhiêu dịch vụ kỹ thuật mới và chuyên sâu. Trong đó phân tích danh sách các dịch vụ kỹ thuật mới được phê duyệt triển khai tại bệnh viện có thể thấy rõ ràng điêu này: Phẫu thuật vi phẫu - tạo hình, Phẩu thuật tái tạo tuyển vú, Phẫu thuật bảo tồn tuyến vú, Phẫu thuật nội soi, Phẫu thuật ghép xương bằng vật liệu thay thế tức thì sau cắt đoạn xương hàm, Cắt u lành tính thanh quản bằng Laser, Cắt ung thư thanh quản bằng Laser, Xa trị bằng máy gia tốc có điều biến liều, Xạ trị bằng máy gia tốc TrueBeam, Phẫu thuật nội soi tuyến giáp qua ngả miệng; các dịch vụ được cung cấp bởi máy xạ Truebeam; như VMAT, IMRT, SBRT...

Xu hướng nguồn thu của bênh viện trong thời gian tới còn có nhiều điểm tiếp tục gia tăng do ảnh hưởng bởi bối cảnh cơ cấu bệnh tật nói chung. Cụ thể, Isố ca mắc mới ung thư tại Việt Nam không ngừng gia tăng, từ 68.000 ca năm 2000 lên 165.000 vào năm 2018 [4]. Trong thời gian tới ảnh hưởng của yếu tố dịch tễ và gánh nặng bệnh tật nói trên không chỉ ảnh hưởng lớn đến quản lý tài chính của Bệnh viện Ung Bướu TP.Hồ Chí Minh mà còn là các bênh viện khuyên khoa ung bướu và các bệnh viện đa khoa có khoa ung bướu trên toàn quốc.

\section{KẾT LUÂN}

Các yếu tố bên trong ảnh hưởng đến kết quả hoạt động tài chính đã được chỉ ra trong y văn nước ngoài và trong nước đã được khẳng định một lần nữa đối với kết quả hoạt động tài chính của Bệnh viện Ung bướu Tp Hồ Chí Minh từ 2014 - 2018: cấu trúc đặc thù (bệnh viện chuyên khoa tuyến cuối, sợ mở rộng cơ sở 2; sự vận hành linh hoạt của bệnh viện giúp tăng cường số lượng và chất lượng hoạt động chuyên môn; chiến lược phát triển bệnh viện thành cơ sở y tế kỹ thuật cao có sự phối hợp liên chuyên khoa; đặc điểm về nhân lực bệnh viện. Bên cạnh các yểu tố kề trên, nghiển cứu này còn chỉ ra yếu tố bên trong khác liên quan đến ảnh hưởng của hệ thống công nghệ thông tin bệnh viện.

Các yếu tố bên ngoài gồm ảnh hưởng của chính sách (chỉnh sách tự chủ, BHYT, viện phí); ảnh hưởng của "thị trường" (bao gồm sự gia tăng của số người mới mắc ung thư và số lượng người mắc ung thư đến bệnh viện điều trị trong giai đoạn muộn; ảnh hưởng của các bệnh viện 
đa khoa có khoa điều trị ung thư trên địa bàn) cũng được chỉ ra là có tác động đến hoạt động quản lý thu chi của bệnh viện trong hiện tại cũng như trong tương lai.

\section{TÀI LIỆU THAM KHẢO}

1. Nurettin Oner (2016), Organizational and Environmental Factors Associated with Hospital Financial Performance: A Systematic Review
2. Nguyễn Thị Bích Hường (2012), Đánh giá một số kết quả sau 5 năm thực hiện tự chủ tài chính tại Bênh viên hữu nghi Viêtt Đ̇ức (2007-2011), Luân văn Thạc sĩ Trường Đại học Y tế công cộng, Hà Nội.

3. Nguyến Thi Nhan (2017), Kết quả hoạt đông thu chi tài chính tại Trung tâm Dich vụ Y tế Bệnh viên Đa khoa Tỉnh Khánh Hòa giai đoan 2014 - 2016

4. Global Cancer Statistics (2018), GLOBOCAN Estimates of Incidence and Mortality Worldwide for 36 Cancers in 185 Countries

\section{NGHIÊN CỨU TỈ LÊ TYPE VIRUS DENGUE Ở BÊNNH NHÂN NHI TRONG MộT SỐ ĐợT DİCH TẠI KHU VỰC MIỀN NAM VIỆT NAM}

\section{TÓM TẮT}

Mục tiêu: Phân tích tỉ lệ type huyết thanh virus Dengue ở bênh nhân nhi trong một số đợt dịch tai Thành phố Hồ Chí Minh, Tiền Giang và Đồng Nai. Đối tượng và phương pháp nghiên cứu: 344 bệnh nhân nhi được chẩn đoán sốt xuất huyết Dengue giai đoạn cấp tính trong vòng 3 ngày của sốt, được nhập viên điều tri tai khoa nhi bênh viên Nhi Đồng 1 , bênh viện Tiền Giang và bệnh viện Nhi Đồng Đồng Nai từ tháng 1-2011 đến tháng 12-2015.Tất cả các bênh nhân đều được thân nhân và người nhà đồng ý tham gia nghiên cứu. Tiến hành thu thập huyết thanh của bệnh nhân, tách RNA. Sử dụng phản ứng Multiplex RंT-PCR xác đinh các type huyết thanh của virus DENV. Kết quả: Bệnh nhân nhiếm type 1 (DENV-1), type 2 (DENV-2), type 3 (DENV-3) và type 4 (DENV4) chiếm tỉ lệ lần lượt là $34,01 \%, 19,77 \%, 5,52 \%$ và $40,70 \%$. Kết luận: Xuất hiện đủ cả 4 type huyết thanh virus Dengue ở các đợt dịch trong thời gian nghiên cứu, với type 4 (DENV-4) chiếm tỉ lệ cao nhất và thấp nhất là type 3 (DENV-3.

Tư khóa: virus dengue, type huyết thanh, nhi.

\section{SUMMARY}

INCIDENCE OF DENGUE VIRUS INFECTION IN PEDIATRIC PATIENTS IN SOME EPIDEMIC OUTBREAKS IN SOUTHERN VIETNAM

Objectives: To analyze the prevalence of dengue virus infection in pediatric patients in several epidemics in Ho Chi Minh City, Tien Giang, and Dong Nai provinces. Subjects and methods: 344 pediatric patients diagnosed with febrile dengue phase within three days of fever, admitted to the Department of Pediatrics at Children Hospital No.1 in Ho Chi Minh City, Tien Giang General Hospital and Dong Nai Children Hospital from January 2011 to December

'Bệnh viện Quân y 103

${ }^{2}$ Hoc viên Quân y

Chịu trách nhiệm chính: Đặng Thành Chung

Email: dangthanhchung@vmmu.edu.vn

Ngày nhận bài: 15.3.2021

Ngày phản biên khoa hoc: 10.5.2021

Ngày duyệt bài: 17.5.2021

\section{Nguyễn Đức Thuận', Đặng Thành Chung²}

2015, Participation in the study was voluntary and agreed to participate in the study by their relatives and family members. Carry out serum collection of the patient, RNA extraction. Using Multiplex RT-PCR reaction to determine dengue virus serotypes. Results: Patients infected with type 1 (DENV-1), type 2 (DENV-2), type 3 (DENV-3) and type 4 (DENV-4) accounted for $34.01 \%, 19,77 \%, 5.52 \%$ and $40.70 \%$ respectively. Conclusion: There are all four dengue virus serotypes in outbreaks during the study period, with Type 4 (DENV-4) has the highest proportion, and the lowest is type 3 (DENV-3).

Key words: dengue virus, serotypes, pediatric.

\section{I. ĐẶT VẤN ĐỀ}

Hiện nay virus Dengue lưu hành và gây dịch tại trên 100 quốc gia và vùng lãnh thổ chủ yếu ở vùng nhiệt đới như Đông Nam Á, Tây Thái Bình Dương, Châu Phi, Châu Mỹ, Địa Trung Hải. Nhiều nghiên cứu đã cho thấy rằng sau khi đi du lịch thì sốt xuất huyết dengue (SXHD) là nguyên nhân gây sốt phổ biến thứ 2 trong các bệnh nhiệt đới sau sốt rét [1]. Tỉ lệ nhiếm virus Dengue (DENV) đã tăng đáng kể trên toàn thế giới trong thập kỷ gần đây, với ước tính khoảng 3,9 tỉ người trong số 128 quốc gia có nguy cơ bị nhiễm virus Dengue. Trong những năm 2010, 2013 và 2015 có khoảng 2,4 triệu người bị nhiễm hàng năm [1]. Có 4 type virus dengue xuất huyết. Tất cả các type này đều gây bệnh sốt dengue (DF) và SXHD. Bệnh SXHD gần như xảy ra trên toàn cầu và bao trùm một vùng với dân số khoảng 2.5 tỷ người - 40\% dân số thế giới. Theo thông báo của Tổ chức $Y$ tế Thế giới (WHO), có từ 50 đến 100 triệu ca bệnh mỗi năm [2].

Tại việt Nam trường hợp SXHD đầu tiên được phát hiên ở Đà Nẳng năm 1958 [3], cho đến nay tất cả bốn type virus của virus DENV đã được thấy lưu hành với ưu thế khác nhau của từng type là khác nhau theo thời gian. Theo các báo cáo từ Viện vệ sinh dịch tễ Trung ương cho 